TAGIEVA K.R., AZIZOV I.V.

Institute of Molecular Biology and Biotechnologies of Azerbaijan National Academy of Sciences, AZ 1073 Baku, Izzat Nabiyev str., 11, e-mail:ktag908@gmail.com, ibrahim.azizov47@gmail.com

\title{
IMPACT OF NaCI ON PHYSIOLOGICAL AND BIOCHEMICAL CHARACTERISTICS OF MAİZE (ZEA MAYS L.) PLANTS
}

\begin{abstract}
Aim. The effect of 50 and $100 \mathrm{mmol} \mathrm{NaCl}$ concentrations on seed germination, the content of green pigments in seedlings, and on the activity of photosystem II in seedlings of maize varieties Zagatala 420, Zagatala 514, Zagatala 68 and Gurur and hybrid Gurur x Zagatala 68 was studied. Methods. Plant seeds were germinated under laboratory conditions in Petri dishes and pots with soil using 50 and $100 \mathrm{mmol}$ of sodium chloride solutions. Germination, seed germination energy had been determined. In two-week old seedlings determined the number of photosynthetic pigments and the activity of photosystem II. Results. High concentrations $(100 \mathrm{mmol})$ of $\mathrm{NaCl}$ reduced seed germination, pigments number, and photosystem II activity. At a salt concentration of $100 \mathrm{mmol}$, an increase in the carbohydrate content was noted. Conclusions. Varieties Gurur and Zagatala 68 and hybrid Gurur x Zagatala 68 were more tolerant compared to varieties Zagatala 420, Zagatala 514.
\end{abstract}

Keywords: maize, $\mathrm{NaCl}$, photosynthetic pigments, photosystem II.

Salinization of soils is one of the main environmental factors that reduce the growth, development and productivity of plants, including maize. Currently, about $20 \%$ of the world's soils are subject to varying degrees of salinization. Maize (Zea mays L.) is one of the important crops and grown in many countries of the world. Maize is C4 plant from the Poaceae family and is moderately sensitive to salt stress $[3,5,6]$. Maize has a wide range of intraspecific genetic variations. This allows you to obtain more genetically tolerant genotypes by crossing existing varieties [7]. $\mathrm{NaCl}$ above a concentration of $0.25 \mathrm{~mol}$ damages corn plants and can inhibit growth and cause severe wilting. Sodium is the main component that inhibits the absorption of potassium, and thus, causing severe water loss, upsets the balance of sodium and potassium ions in the cells of corn leaves [10]. In addition, salt stress also causes oxidative damage to cells with the overproduction of reactive oxygen species [1].
The aim of this work was to study the effect of different concentrations of sodium chloride on the morphophysiological characteristics of maize genotypes.

\section{Materials and methods}

The object of research was the genotypes of maize Zagatala 420, Zagatala 514, Zagatala 68, and Gurur. Plant seeds germinated under laboratory conditions in Petri dishes and pots with soil using 50 and $100 \mathrm{mmol}$ of sodium chloride solutions. Germination, seed germination energy had determined. In two-week old seedlings determined the number of photosynthetic pigments and the activity of photosystem II. Content of chlorophylls and carotenoids was determined on a spectrophotometer (SP-2000), fluorescence on a photosynthesis analyzer (PAM-Germany), and the photochemical activity of chloroplasts on a polarograph $(\mathrm{OH}-103$ Hungary). The content of chlorophyll a, b and carotenoids was determined at a wavelength of 665 , 645 and 440, respectively, using the Wintermans [11]. The activity of photosystem 2 was determined using a $F_{v} / F_{m}$ coefficient, where $F_{v}=F_{m}-F_{0} ; F_{0}-$ fluoressence of "dark" leaves, $F_{m}$ - fluoressence of "light" leaves. Determination of soluble sugars carried out by the anthrone-sulfuric acid method [4]. Statistical data processing performed using the Excel program in triplicate.

\section{Results and discussion}

It revealed that under the influence of salt, germination and germination energy of corn seeds reduced. With the increase of sodium chloride concentration decreased the photochemical activity of chloroplasts and the content of photosynthetic pigments in seedlings. There were observed differences between varieties in the activity of photosystems at high salt concentrations. Under the conditions of salt action, a slight increase in the content of soluble sugars was found in all genotypes of maize (Table).

\footnotetext{
${ }^{\circledR}$ TAGIEVA K.R., AZIZOV I.V.
} 
Table. Influence of various sodium chloride concentrations on seed germination, pigment content, sugars, and photosystem II activity in seedlings of maize varieties

\begin{tabular}{|c|c|c|c|c|c|c|}
\hline Varieties & $\begin{array}{l}\mathrm{NaCl}, \\
(\mathrm{mM})\end{array}$ & $\begin{array}{l}\text { Germination } \\
(\%)\end{array}$ & $\begin{array}{c}\mathrm{Xla}+\mathrm{Xlb} \\
(\mathrm{mq} / \mathrm{g})\end{array}$ & $\begin{array}{l}\text { Sugars, } \\
\mathrm{mg} / \mathrm{g}\end{array}$ & $\begin{array}{l}\text { Karotenoids } \\
\quad(\mathrm{mq} / \mathrm{g})\end{array}$ & $\mathrm{Fv} / \mathrm{Fm}$ \\
\hline \multirow{3}{*}{ Gurur } & 0 & $90 \pm 1$ & $11,4 \pm 1,2$ & 7,8 & $2,8 \pm 0,9$ & 0,75 \\
\hline & 50 & $85 \pm 2$ & $16,9 \pm 1,3$ & 8,8 & $3,4 \pm 0,5$ & 0,70 \\
\hline & 100 & $70 \pm 4$ & $10,4 \pm 1,2$ & 12,5 & $2,3 \pm 0,3$ & 0,65 \\
\hline \multirow{3}{*}{ Zagatala-514 } & 0 & $86 \pm 1$ & $14,5 \pm 1,4$ & 7,9 & $3,5 \pm 0,5$ & 0,72 \\
\hline & 50 & $50 \pm 4$ & $12,0 \pm 1,1$ & 8,2 & $3,3 \pm 0,6$ & 0,66 \\
\hline & 100 & $20 \pm 3$ & $4,5 \pm 0,9$ & 9,9 & $1,4 \pm 0,4$ & 0,55 \\
\hline \multirow{3}{*}{ Zagatala-68 } & 0 & $88 \pm 2$ & $10,0 \pm 0,9$ & 9,8 & $2,8 \pm 0,2$ & 0,73 \\
\hline & 50 & $70 \pm 1$ & $13,6 \pm 1,2$ & 12,7 & $3,5 \pm 0,5$ & 0,71 \\
\hline & 100 & $65 \pm 1$ & $10,7 \pm 1,5$ & 14,4 & $2,3 \pm 0,6$ & 0,64 \\
\hline \multirow{3}{*}{ Zagatala 420} & 0 & $90 \pm 2$ & $11,4 \pm 2,1$ & 9,5 & $2,9 \pm 0,5$ & 0,75 \\
\hline & 50 & $60 \pm 4$ & $8,6 \pm 1,6$ & 12,2 & $2,6 \pm 0,6$ & 0,65 \\
\hline & 100 & $25 \pm 3$ & $5,8 \pm 1,2$ & 13,8 & $1,3 \pm 0,7$ & 0,59 \\
\hline \multirow{3}{*}{$\begin{array}{l}\text { F1 Gurur x } \\
\text { Zagatala-68 }\end{array}$} & 0 & $90 \pm 3$ & $12,6 \pm 2,1$ & 13,2 & $3,2 \pm 0,5$ & 0,81 \\
\hline & 50 & $86 \pm 2$ & $15,2 \pm 3,2$ & 14,1 & $4,8 \pm 0,4$ & 0,72 \\
\hline & 100 & $75 \pm 5$ & $12,3 \pm 2,1$ & 16.8 & $3,9 \pm 0,5$ & 0,69 \\
\hline
\end{tabular}

As can be seen from the table, with increasing concentration, the percentage of seed germination, the content of chlorophyll and carotenoids, and the activity of photosystem II decrease. At a salt concentration of $50 \mathrm{mmol}$, the pigment content and the activity of chloroplasts in the genotypes Gurur and Zagatala 68, in contrast to the genotypes Zagatala 420 and Zagatala 514, increase. At a salt concentration of $100 \mathrm{mmol}$, the activity of genotypes Zagatala 420 and Zagatala 514 decreases, while in varieties Gurur and Zagatala 68, also in first generation hybrid Gurur x Zagatala 68 remains at the control level. The table also shows that with increasing salt concentration, the content of soluble sugars in the leaves of all varieties increases.

It is generally known that photosynthesis iss the most important process by which green plants convert solar energy into chemical energy in the form of organic compounds synthesized by fixation of atmospheric carbon dioxide. Carbon fixation in maize is very sensitive to salt stress. Both stomatal and nonstomatal limitations and their combination are associated with salinity-induced reductions in maize photosynthesis. Reduced stomatal conductance, impaired activities of carbon fixation enzymes, reduced photosynthetic pigments, and destruction of photosynthetic apparatus. Salinity is known to limit photosynthesis which can enhanced oxygen induced cellular damage due to increased production of reactive oxygen species. So, tolerance to any stress condition, salinity stress as studied here, should partly depend on the enhancement of antioxidant defense system. Antioxidative enzymes are known to protect the cell structures against the reactive oxygen species generated by stress conditions are among the key factors limiting carbon fixation capacity of maize plants under salt stress. Total photosynthesis decreases due to inhibited leaf development and expansion, as well as early leaf abscission, and as salt stress is prolonged, ion toxicity, membrane disruption, and complete stomatal closure become the prime factors responsible for photosynthetic inhibition. Munns and Tester identified the reduction in stomatal aperture as 
the most dramatic and readily measurable wholeplant response to salinity and also concluded that the osmotic effect of salt outside the roots induces stomatal responses. Salt stress affects stomatal conductance immediately due to perturbed water relations and shortly afterward due to the local synthesis of abscisic acid. As a C4 plant, maize uses NADP-malic enzyme-type photosynthesis and these plants fix atmospheric carbon dioxide principally into oxaloacetate through phosphoenolpyruvate carboxylase in mesophyll cells. Oxaloacetate is then transported to mesophyll cell chloroplasts and reduced to malate by the NADP-dependent malate dehydrogenase enzyme. Malate is then shifted to bundle sheath cells of chloroplasts and decarboxylated by NADP-malic enzyme to provide carbon dioxide and reducing power. This carbon dioxide is fixed by ribulose-1,5-bisphosphatecarboxylase/oxygenase (Rubisco) via the Calvin cycle as per C3 plants. In that way, higher carbon dioxide contents near Rubisco in the bundle sheath cells restrain oxygenase activity and help to improve photosynthesis compared with $\mathrm{C} 3$ plants at the expense of reduced photorespiration. Activities of C4 photosynthetic enzymes like pyruvate orthophosphate kinase, phosphoenolpyruvate carboxylase, NADP-dependent malate dehydrogenase, and NAD-dependent malate dehydrogenase tend to increase under salt stress in maize even though the structure of mesophyll cell chloroplasts is damaged. In contrast, in bundle sheath cells, activities of NADP-malic enzyme and Rubisco decrease without any visual symptoms of damage to chloroplasts in bundle sheath cells. Moreover, pyruvate orthophosphate kinase protein content increases, but phosphoenolpyruvate carboxylase protein content decreases in maize due to salinity $[8,9]$. Gas exchange analysis confirmed that reductions in net photosynthetic rate are connected with the limited availability of intercellular carbon dioxide due to reduced rates of transpiration and stomatal conductance in salt-treated maize plants. It known that under the salt stress, the external water potential decreases, absorption of biogenic metal ions by the roots becomes difficult, and the chlorine and sodium ions have a toxic effect on plant metabolism. These three possible effects of salt stress have a detrimental effect on plant growth, development and yield. $[4,8,9]$. Osmotic stress is associated with the accumulation of ions in the soil solution, while malnutrition and the specific effects of ions are associated to the accumulation of ions, mainly sodium and chloride, to toxic levels which inhibits the availabil- ity of other important elements such as calcium and potassium [2,9]. Toxic levels of sodium in plant organs damage biological membranes and subcellular organelles, reducing growth and causing abnormal development before plant death. Several physiological processes, such as photosynthesis, respiration, starch metabolism and nitrogen fixation also disrupted in salt conditions, which leads to a decrease in crop productivity. In response to this, the plant synthesizes low molecular weight solutes, including soluble carbohydrates for better absorption of water during salinity. The increase in sugars mostly results in increased starch hydrolysis, which requires activities of hydrolytic enzymes. Resurrection plants and seeds of many higher plants are good examples for a link of carbohydrate (in particular sucrose) accumulation and the acquisition of stress tolerance This is illustrated with the example of the resurrection plant Craterostigma plantagineum, which contains a high amount of the unusual sugar octulose (an 8-carbon sugar), which is rapidly converted into sucrose during dehydration. This sugar conversion is coupled with the increased expression of sucrose synthase and sucrose phosphate synthase genes. The currant hypothesis is that sugars either act as osmotica and/or protect specific macromolecules and contribute to the stabilization of membrane structures. Sugars may protect cells during desiccation by forming glasses. Sugars are also thought to interact with polar headgroups of phospholipids in membranes so that membrane fusion is prevented. It is unknown whether sugars fulfil this function on their own or in conjunction with other molecules such as Late embryogenesis abundant proteins. Late embryogenesis abundant proteins are mainly low molecular weight (10$30 \mathrm{kDa}$ ) proteins, which are involved in protecting higher plants from damage caused by environmental stresses, especially drought (dehydration). These findings and the fact that the breeding of drought tolerant varieties would be of great value in agriculture, form the basis of search for anti-drought inducible genes and their characterization. Late embryogenesis abundant proteins are generally classified into six groups (families) according to their amino acid sequence and corresponding mRNA homology, which are basically localized in cytoplasm and nuclear region. Late embryogenesis abundant protein synthesis, expression and biological activities are regulated by many factors (e.g. developmental stages, hormones, ion change and dehydration), signal transduction pathways and lea 
genes. Many seeds accumulate considerable amounts of raffinoase-type oligosaccarides such as raffinose and stachyose which are thought to play a role in the acquisition of desiccation tolerance. Despite many studies the link between the presence of these carbohydrates and desiccation tolerance has not always been confirmed.Genotypes with a powerful genetic apparatus cope with this task and grow well in salt conditions. In the process of evolution, protective mechanisms against adverse environmental factors formed in all organisms, including plants. Therefore, when assessing resistance to stress factors, it is necessary to take into account the individual properties of each plant genotype.

\section{Conclusions}

At concentrations of $\mathrm{NaCl}$ solution of 100 mmol decreased seed germination, pigment content, and photosystem II activity in seedlings of maize genotypes. Varieties Gurur and Zagatala 68, and their hybrid Gurur x Zagatala 68 were resistant to high salt concentrations. Thus, by crossing relatively resistant maize genotypes, more resistant hybrids can be obtained.

\section{References}

1. Azevedo Neto A.D., Prisco J.T., Eneas J., de Abreu C.E.B., Gomes-Filho E. Effect of salt stress on antioxidative enzymes and lipid peroxidation in leaves and roots of salt-tolerant and salt sensitive maize varieties. Environ. Exp. Bot. 2006. No. 56. P. 87-94.

2. Bassiouny H.M., Bekheta M.A. Role of putrescine on growth, regulation of stomatal aperture, ionic contents and yield by two wheat cultivars under salinity stress. Egypt J. Physiol. Sci. 2001. No. 2-3. P. 239-258.

3. Chinnusamy V., Jagendorf A., Zhu J.K. Understanding and improving salt tolerance in plants. Crop Sci. 2005. No. 45. P. 437-448. doi: 10.2135 .

4. $\quad$ Flowers T.J., Flowers S.A. Why does salinity pose such a difficult problem for plant breeders? Agric. Water Manag. 2005. Vol. 78. P. 15-24. doi: 10. 1016.

5. Maas E.V., Hoffman G.J. Crop salt tolerance-current assessment. J. Irrig Drain. Div. ASCE. 1977. No. 103. P. $115-134$.

6. Maas E.V., Hoffman G.J., Chaba G.D., Poss J.A., Shannon M.C. Salt sensitivity of corn at various growth stages. Irrig. Sci. 1983. No. 4. P. 45-57.

7. Mansour M.M.F., Salama K.H.A., Ali F.Z.M., Hadid A.F. Cell and plant responses to $\mathrm{NaCl}$ in Zea mays cultivars differing in salt tolerance. Gen. Appl. Plant Physiol. 2005. No. 31. P. 29-41.

8. Farooq M., Hussain M., Wakeel A., Kadambot H. M. Siddique. Salt stress in maize: effects, resistance mechanisms, and management. A review. Agronomy for Sustainable Development, Springer Verlag/EDP Sciences/INRA. 2015. Vol. 35 (2). P. 461-481.

9. $\quad$ Munns R., James R.A., Läuchli A. Approaches to increasing the salt tolerance of wheat and other cereals. J. Exp. Bot. 2006. Vol. 57. P. 1025-1043.

10. Shahzad M., Witzel K., Zorb C., Muhling K.H. Growth-related changes in subcellular ion patterns in maize leaves (Zea mays L.) under salt stress. J Agron. Crop Sci. 2012. No. 198. P. 46-56.

11. Wintermans J.E.G., De Mots A. Spectrophotometric Characteristics of Chlorophyll a and b and Their Phaeophytins in Ethanol. Biochimica et Biophysica Acta. 1965. Vol. 109. P. 448-453.

ТАГІЄВА К. Р., АЗІЗОВ І. В.

Інститут молекулярної біології та біотехнології Національної академії наукАзербайджан, AZ 1073, м. Баку, вул. Іззата Набісва, 11, е-mail: ktag908@ gmail.com, ibrahim.azizov47@gmail.com

\section{ВПЛИВ NaCI НА ФІЗІОЛОГІЧНІ ТА БІОХІМІЧНІ ХАРАКТЕРИСТИКИ РОСЛИН КУКУРУДЗИ (ZЕА MAYS L.)}

Mema. Вивчення впливу концентрацій $\mathrm{NaCl} 50$ і 100 ммоль на схожість насіння, вміст зелених пігментів та на активність фотосистеми II у проростках кукурудзи сортів Загатала 420, Загатала 514, Загагата 68 та Гурур та гібрида Гурур Х Загагата 68. Методи. Насіння рослин, пророщене в лабораторних умовах у чашках Петрі і горщиках 3 грунтом, із застосуванням 50 і 100 ммоль розчинів хлориду натрію. Визначили схожість та енергію проростання насіння. У двотижневих проростках визначали кількість фотосинтетичних пігментів та активність фотосистеми ІІ. Результати. Високі концентрації (100 ммоль) $\mathrm{NaCl}$ знижують схожість насіння, кількість пігментів та активність фотосистеми II. За концентрації солі 100 ммоль відзначено збільшення вмісту вуглеводів. Висновки. Сорти Gurur i Zagatala 68 та гібрид Gurur x Zagatala 68 були більш толерантними порівняно із сортами Zagatala 420, Zagatala 514.

Ключові слова: кукурудза, $\mathrm{NaCl}$, фотосинтетичні пігменти, фотосистема II. 